\title{
Structural basis for inhibition of protein tyrosine phosphatases by Keggin compounds phosphomolybdate and phosphotungstate
}

\author{
Yong-Seok Heo', Jung Min Ryu², \\ Sang Myun Park ${ }^{2}$, Jeon Han Park ${ }^{2}$, \\ Hyun-Chul Lee ${ }^{3}$, Kwang Yeon Hwang ${ }^{1,4}$, \\ Jongsun $\mathrm{Kim}^{2,4}$ \\ ${ }^{1}$ CrystalGenomics, Inc., Taejon, Korea \\ ${ }^{2}$ Department of Microbiology and Brain Korea 21 Project of Medical \\ Sciences, Yonsei University College of Medicine, Seoul, Korea \\ ${ }^{3}$ Department of Internal Medicine, Yonsei University College of \\ Medicine \\ ${ }^{4}$ Corresponding author: Tel, +82-2-361-5277; \\ Fax, +82-2-392-7088; E-mail: jkim63@yumc.yonsei.ac.kr
}

Accepted 4 July 2002

Abbreviations: PTP, protein tyrosine phosphatase; PTK, protein tyrosine kinase; SHP-1, SH2 domain containing protein tyrosine phosphatase-1; pNPP, p-nitrophenyl phosphate; PM, phosphomolybdate; PT, phosphotungstate; LAR, leukocyte common antigenrelated protein tyrosine phosphatase; PP1, human protein phosphatase 1; CIP, alkaline phosphatase of calf intestine; OBA, 2(Oxalylamino)benzoic acid; bpV, Bis-peroxo(bipyridine)oxovanadate.

\begin{abstract}
Protein-tyrosine phosphatases (PTPs) constitute a family of receptor-like, and cytoplasmic enzymes, which catalyze the dephosphorylation of phosphotyrosine residues in a variety of receptors and signaling molecules. Together with protein tyrosine kinases (PTKs), PTPs are critically involved in regulating many cellular signaling processes. In this study, diverse compounds were screened for PTP inhibition and selectively screened for inhibitors with the end product inhibition properties. Among phosphate analogues and their derivatives for PTP inhibition, Keggin compounds phosphomolybdate (PM) and phosphotungstate (PT) strongly inhibited both PTP-1B and SHP-1, with $K_{i}$ values of 0.06-1.2 $\mu \mathrm{M}$ in the presence of EDTA. Unlike the vanadium compounds, inhibition potencies of PM and PT were not significantly affected by EDTA. PM and PT were potent, competitive inhibitors for PTPs, but relatively poor inhibitors of Ser/Thr phosphatase. Interestingly, PM and PT did not inhibit alkaline phosphatase at all. The crystal structure of PTP-1B in complex with PM, at $2.0 \AA$ resolution, reveals that
\end{abstract}

$\mathrm{MoO}_{3}$, derived from PM by hydrolysis, binds at the active site. The molybdenium atom of the inhibitor is coordinated with six ligands: three oxo-ligands, two apical water molecules and a $S$ atom of the catalytic cysteine residue. In support of the crystallographic finding, we observed that molybdenium oxides $\left(\mathrm{MoO}_{3}, \mathrm{MoO}_{2}\right.$, and $\left.\mathrm{MoO}_{2} \mathrm{Cl}_{2}\right)$ inhibited PTP-1B with ${ } \mathrm{CC}_{50}$ in the range 5-15 $\mu \mathrm{M}$.

Keywords: Protein-tyrosine-phosphatase, molybdenum, tungsten compounds, enzyme inhibitors, crystallography

\section{Introduction}

Reversible protein tyrosine phosphorylations, controlled by competing activities between protein-tyrosine kinases (PTKs) (Zhang, 1998) and protein-tyrosine phosphatases (PTPs), are critically involved in regulating many cellular signaling processes, where the propagation and termination of signaling events are determined by the level of protein tyrosine phosphorylation (Fischer et al., 1991, Hunter, 1995, Neel and Tonks, 1997, Zhang, 1998). Classical PTP family members can be classified into two groups, receptor-like PTPs, which are represented by LAR (leukocyte common antigen-related protein tyrosine phosphatase) and PTP $\alpha$, and cytosolic PTPs, which are represented by PTP-1B and SHP-1 (Denu and Dixon, 1998, Hooft van Huijsduijnen, 1998). PTPs have been considered to have extremely low substrate specificity, since they are known to dephosphorylate multiple target molecules unrelated to one another, when assayed in vitro, or by overexpression in cells (Zhang and Dixon, 1994, Tonks and Neel, 1996). However, recently reported knockout mice, deficient of particular PTPs, all appear to exhibit unique phenotypes, suggesting each PTP has a specific, or very limited target molecule(s) in vivo (Kishihara et al., 1993, Shultz et al., 1993, Tsui et al., 1993, Saxton et al., 1997, Schaapveld et al., 1997, You-Ten et al., 1997, Cote et al., 1998, Ren et al., 1998, Elchebly et al., 1999a, Elchebly et al., 1999b). Therefore, highly selective PTP inhibitors could be used as therapeutic agents for diseases, as well as for the elucidation of biological functions of enzymes.

Based on the potential therapeutic and biological usefulness of selective PTP inhibitors, significant progress in developing such agents is being made (Burke and Zhang, 1998, Kennedy and Ramachandran, 2000). For example, vanadate and its derivatives such 
as peroxovanadium complexes are one of the best characterized PTP inhibitors, but appear to be nonspecific among the PTP family members (Swarup et al., 1982, Posner et al., 1994, Huyer et al., 1997,). PTP substrate analogues, in which the cleavable O-P linkage has been replaced by PTP-resistant chemical linkage, such as sulfotyrosine, thiophosphotyrosine, O, O-dicar boxymethyltyrosine, phosphonomethyl phenylalanine, and 4-[difluoro(phosphono)methyl]phenylalanine, have been shown as potent inhibitors of PTPs (Burke et al., 1994, Liotta et al., 1994, Zhang et al., 1994, Kole et al., 1995, Burke et al., 1996, Huyer et al., 1998, Desmarais et al., 1999). Particularly, phosphonate compounds incorporated in peptides are being developed as relatively selective inhibitors of PTPs (Chen et al., 1995, Taing et al., 1999). Recently, simple organic molecules such as 2-(oxalylamino)benzoic acid (OBA) and its derivatives (Andersen et al., 2000, Iversen et al., 2000), and benzofuran and benzothiophen biphenyls compounds (Malamas et al., 2000) have turned out to be potent inhibitors.

In this study, we embarked on identifying general, potent, reversible PTP inhibitors that could be used as lead compounds for developing selective PTP inhibitors, focusing on the end product inhibition properties of PTPs. We screened various derivatives of phosphate, and phosphate analogues, for the PTP inhibition, and found that Keggin compounds phosphomolybdate (PM) and phosphotungstate (PT) strongly inhibited the PTPs.

\section{Materials and Methods}

\section{Materials}

An E. coli expression vector, pRSETA, was purchased from Invitrogen (Carlsbad, CA), and an E. coli strain for the protein expression, BL21 (DE3) pLysS, was from Stratagene (La Jolla, CA). Bradford solution, for protein assays, was purchased from Bio-Rad (Hercules, CA). Centriprep and Centricon were purchased from Amicon (Berverly, MA), and DEAE sepharose CL-6B was from Amersham Pharmacia (Uppsala, Sweden). p-Nitophenyl phosphate (pNPP), sodium orthovanadate, sodium molybdate, sodium tungstate, PM, PT vanadyl sulfate, thiophosphate, glutathion (GSH), leupeptin, dithiothreitol and isopropyl $\beta$-D-I-thiogalactopyranoside (IPTG) were purchased from Sigma (St. Louis, MO). Bisperoxo(bipyridine)oxovanadate (bpV), a peroxovanadium compound (Posner et al., 1994) was purchased from Alexi Biochemicals (San Diego, CA). The catalytic domains of LAR, PP1 (the $\gamma$ form of human protein phosphatase 1) and CIP (alkaline phosphatase of calf intestines) were purchased from New England Biolab (Berverly, MA).
PCR cloning and expression of the catalytic domains of PTP-1B and SHP-1

Total RNA was isolated from peripheral blood mononuclear cells (PBMCs) of a heathy volunteer, and the first strand CDNA of the total RNA was synthesized as described previously (Kim et al., 1997). The protein coding region of the catalytic domain of PTP-1B (Chernoff et al., 1990) was amplified by PCR using $10 \mu \mathrm{l}$ of the CDNA and Taq polymerase with the $5^{\prime}$-oligonucleotide primer 5'-CGGATCCATATGGAGATGGAA AAGGAGTTC and the 3'-oligonucleotide primer 5'CCGTACGGATCCTTAATTGTGTGGCTCCAGGATTCG, containing the underlined $\mathrm{Ndel}$ and $\mathrm{BamHI}$ restriction sites, respectively. The protein coding region of the catalytic domain of SHP-1 (Shen et al., 1991) was amplified similarly with the $5^{\prime}$-oligonucleotide primer 5 '-G GAATTCCATATGGGCTTCTGGGAGGAGTTTGAG and the 3'-oligo nucleotide primer 5 '-GGGAAGCTT CTAATAGGTGATGTTCCCGTA, containing the underlined Ndel and HindlII restriction sites, respectively. The amplified DNAs were gel purified, digested with appropriate restriction enzymes, and ligated into an $E$. coli expression vector, pRSETA, which had been previously digested with the restriction enzymes, and gel purified. The recombinant DNAs were transformed into the $E$. coli strain $\mathrm{DH} 5 \alpha$, and clones containing the correct insert were identified by restriction digest, and the inserts confirmed by DNA sequencing.

The plasmids containing the catalytic domain of PTP-1B and SHP-1 were transformed into the E. coli strain BL21 (DE3) pLysS for protein expression. Three liters of bacteria, carrying the recombinant plasmids, were grown from a single colony at $37^{\circ} \mathrm{C}$ in LB medium containing 100 $\mu \mathrm{g} / \mathrm{ml}$ of ampicilin, and induced with $0.5 \mathrm{mM} \mathrm{IPTG}$ at $\mathrm{OD}_{600}$ of 0.8 . Four hours after the induction, bacteria were harvested by centrifugation.

\section{Purification of the Recombinant PTP-1B and SHP-1}

The recombinant PTP-1B was purified by conventional column chromatographic techniques. The bacterial pellet was disrupted by sonication at $4^{\circ} \mathrm{C}$ in a lysis buffer containing $25 \mathrm{mM}$ Tris- $\mathrm{HCl}, \mathrm{pH}$ 7.5, $10 \mathrm{mM} \beta$-mercaptoethanol, $10 \mathrm{mM}$ EDTA, $0.002 \%$ phenylmethylsulfonyl fluoride and $20 \mu \mathrm{g} / \mathrm{mL}$ leupeptin. The homogenate was then centrifuged for 10 min at $4^{\circ} \mathrm{C}$ at $10,000 \mathrm{rev} . / \mathrm{min}$. The supernatant containing the soluble form of PTP-1B was loaded onto a DEAE Sepharose-CL $6 \mathrm{~B}$ column, which was pre-equilibrated with QA buffer ( $25 \mathrm{mM}$ Tris- $\mathrm{HCl}$, pH 7.5, 2 mM $\beta$-mercaptoethanol, $1 \mathrm{mM}$ EDTA). The column was washed with the QA buffer and the bound proteins were eluted from the column using a linear gradient from 0 to $0.5 \mathrm{M} \mathrm{NaCl}$ in 200 $\mathrm{mL}$ of QA buffer. The eluted PTP-1B fractions were pooled, concentrated, and further purified on an FPLC gel-filtration 
column equilibrated with $\mathrm{QA}$ buffer.

The recombinant SHP-1 protein was overexpressed as insoluble forms (inclusion bodies) in E. coli, thus the protein was purified after refolding the isolated inclusion bodies. The inclusion body proteins of SHP-1 were isolated as described previously (Garboczi et al., 1992, Kim et al., 1997). Refolding of the denatured SHP-1 protein was performed by a dilution method in the presence of a glutathione redox buffer. After refolding, the refolding mixture was concentrated with Centriprep and Centricon to a volume of 0.5 to $1 \mathrm{ml}$. The concentrated protein was subjected to an FPLC gel filtration column equilibrated with QA buffer. The peak fractions were analyzed by SDS-PAGE, and the fractions containing the correctly folded protein were pooled and concentrated with Centricon. Protein purity was checked by SDS-PAGE on a $12 \%$ gel, and the protein concentration was determined using the Bradford dye binding assay.

\section{Phosphatase assay with pNPP}

Phosphatase activity was assayed using pNPP as a substrate. The catalytic activities of PTP-1B, SHP-1 and $\mathrm{CIP}$ were assayed at $37^{\circ} \mathrm{C}$ for $30 \mathrm{~min}$ in a reaction mixture $(0.2 \mathrm{ml})$ containing $10 \mathrm{mM}$ pNPP as substrate. The reaction was initiated by addition of each enzyme, and quenched, after $30 \mathrm{~min}$, by addition of $1 \mathrm{ml}$ of $1 \mathrm{M}$ $\mathrm{NaOH}$. The buffer used was QA buffer with $2 \mathrm{mM}$ dithiothreitol. The catalytic activities of the LAR and PP1 were assayed at $37^{\circ} \mathrm{C}$ for $30 \mathrm{~min}$ in a reaction mixture $(0.1 \mathrm{ml})$ containing $50 \mathrm{mM}$ pNPP as substrate. The buffers used were QA buffer with $2 \mathrm{mM}$ dithiothreitol and $1 \mathrm{mg} / \mathrm{ml}$ BSA for the LAR assay, and QA buffer with 2 $\mathrm{mM}$ DTT and $1 \mathrm{mM} \mathrm{MnCl}_{2}$ for PP1 assay, respectively. The reaction was initiated by addition of each enzyme, and quenched, after $30 \mathrm{~min}$, by addition of $0.1 \mathrm{ml}$ of $2 \mathrm{M}$ $\mathrm{NaOH}$. The ionic strength of each reaction mixture was adjusted using $\mathrm{NaCl}$ to $0.15 \mathrm{M}$. Nonenzymatic hydrolysis of the substrate was corrected by measuring the optical density of the control without the addition of enzyme. The amount of released p-nitrophenol was determined by measuring the absorbance at $405 \mathrm{~nm}$, and quantified by comparing the values with those of control $p$ nitrophenol solutions when necessary.

\section{Determination of kinetic parameters and inhibition constants}

The catalytic activities of PTP-1B and SHP-1 were assayed by measuring the absorbance of hydrolyzed pNPP at $405 \mathrm{~nm}$, as described above. Kinetic parameters $\left(K_{\mathrm{m}}\right.$ and $\left.V_{\max }\right)$ were determined from a direct fit of the velocity versus substrate concentration, to the double reciprocal plot, using Sigmaplot 4.01 (Jandel Scientific). Kinetic parameters were represented as average values, determined from three independent experiments.
The inhibition constant $\left(K_{\mathrm{i}}\right)$ for each inhibitor was determined for PTP1B and SHP-1 as previously described (Wang et al., 1999). Briefly, at various fixed concentrations of each inhibitor (at least 3 or 4 different concentrations), the initial rates at least six different pNPP concentrations $\left(0.2 K_{\mathrm{m}}\right.$ to $\left.5 K_{\mathrm{m}}\right)$ were measured as described by Chen et al. (1996). The data were fitted to the following equation to obtain the inhibition constant of reversible competitive inhibitors.

$$
1 / v=\left\{\left(K_{\mathrm{m}} / V_{\max }\right)\left(1+[\mathrm{l}] / K_{\mathrm{i}}\right)\right\} 1 /[\mathrm{S}]+1 / V_{\max }
$$

The slopes obtained were replotted against inhibitor concentrations using Sigmaplot 4.01. $K_{\mathrm{i}}$ values were obtained from the $x$-intercepts of these replots. For each compound, the inhibition constant was given as a mean of the $K_{\mathrm{i}}$ values, obtained from three independent experiments.

\section{Preparation of PTP-1B crystals}

PTP-1B crystals were grown at $4^{\circ} \mathrm{C}$ in a buffer containing $100 \mathrm{mM}$ Hepes (pH 7.8), $200 \mathrm{mM}$ magnesium acetate, and $18 \%(w / v)$ polyethylene glycol 8000 with $10 \mathrm{mg} / \mathrm{ml}$ of recombinant PTP-1B protein. The PTP-1B:PM complex crystals were prepared by incubating PTP-1B crystals in a cryosolution [100 mM Hepes, pH 7.8, $200 \mathrm{mM}$ magnesium acetate, $18 \%(\mathrm{w} / \mathrm{v})$ polyethylene glycol $8000,25 \%$ (v/ v) glycerol, and $1 \mathrm{mM}$ PM] for $2 \mathrm{~h}$. To achieve uniform distribution of the inhibitor within the crystals, relatively small crystals (dimensions of $0.05 \times 0.05 \times 0.15 \mathrm{~mm}$ ) were used. The incubated crystal was mounted directly into a nylon loop and flash-frozen at $100 \mathrm{~K}$ (Oxford Cryostream cooling device).

\section{Data collection and processing}

Diffraction data were collected using the DIP2030 image plate detector on a synchrotron beam line PLS 6B, at the Pohang Accelerator Laboratory in Korea. $A$ wavelength of $1.1764 \AA$ was used to collect diffraction data with $1.5^{\circ}$ oscillation per frame. The raw data was processed using the HKL software package. For further details, see Table 5 .

\section{Refinement}

In the case of the space group P3121, there is more than one indexing possibility. Thus, a molecular replacement solution was determined using the CNS software package (Brunger et al., 1998) prior to the structure refinement. The initial model used for phase determination was the unliganded PTP-1B structure (Barford et al., 1994), with the WPD loop (residue 179187) deleted. 2Fo-Fc and Fo-Fc electron density maps, calculated after rigid body refinement, clearly showed the electron density for the inhibitor at the active site, and an open conformation of the WPD loop. Three 
cycles of refinement with the CNS, and rebuilding of the model with the QUANTA software package (Molecular Simulations Inc.), resulted in the final model comprising residues 2-279, 118 ordered water molecules, and one $\mathrm{MoO}_{3}$ molecule. All data from 20 to $2.0 \AA$ 为 were used for the final round of refinement employing an isotropic bulk solvent model (Jiang and Brunger, 1994), and it resulted in a final crystallographic R-factor of $0.217 \quad\left(R_{\text {free }}=\right.$ 0.239), with good geometry (Table 5).

\section{Results}

\section{Purification and characterization of the catalytic domains of PTP-1B and SHP-1}

The protein coding regions of the catalytic domain of PTP-1B (amino acid 1-321) (Chernoff et al., 1990) and SHP-1 (amino acid 245-543) (Shen et al., 1991), were cloned into an $E$. coli expression vector. The catalytic domain of PTP-1B was overexpressed in E. coli as a soluble protein, while that of SHP-1 was overexpressed as insoluble protein aggregates (inclusion bodies). The recombinant PTP-1B protein was purified by conventional column chromatographic techniques. The recombinant SHP-1 protein was purified by FPLC gelfiltration chromatography, after refolding of the isolated inclusion bodies in a redox buffer (Garboczi et al., 1992). The catalytic activities of the recombinant PTP$1 \mathrm{~B}$ and SHP-1 were measured spectroscopically using pNPP as substrate (Chen et al., 1996). Both PTP-1B

Table 1. Percent activity of PTP-1B and SHP-1 in the presence of phosphate, phosphate analogues and their derivatives. PTP activities were measured as described in Materials and Methods under various inhibitor concentrations. $10 \mathrm{mM}$ pNPP was used as substrate.

\begin{tabular}{|c|c|c|c|c|c|c|c|c|}
\hline \multirow{4}{*}{ Compounds } & \multicolumn{8}{|c|}{ Enzyme } \\
\hline & \multicolumn{4}{|c|}{ PTP - 1B } & \multicolumn{4}{|c|}{ SHP - 1} \\
\hline & 10 & 50 & 100 & 200 & 10 & 50 & 100 & 200 \\
\hline & \multicolumn{4}{|c|}{$(\mu \mathrm{M})$} & \multicolumn{4}{|c|}{$(\mu \mathrm{M})$} \\
\hline $\mathrm{NaCl}$ & 102 & 104 & 106 & 106 & 102 & 103 & 108 & 112 \\
\hline \multicolumn{9}{|c|}{ Phosphate analogs } \\
\hline Phosphate & 103 & 105 & 104 & 103 & 93 & 94 & 89 & 98 \\
\hline Thiophosphate & 100 & 102 & 103 & 107 & 97 & 73 & 43 & 11 \\
\hline Vanadate & 87 & 34 & 17 & 7 & 58 & 19 & 12 & 6 \\
\hline Molybdate & 65 & 35 & 21 & 14 & 55 & 18 & 22 & 12 \\
\hline Tungstate & 75 & 31 & 13 & 7 & 65 & 24 & 18 & 11 \\
\hline Sulfate & 100 & 99 & 98 & 92 & 108 & 111 & 97 & 107 \\
\hline Thiosulfate & 96 & 96 & 98 & 87 & 85 & 86 & 93 & 80 \\
\hline Metabisulfite & 99 & 98 & 94 & 88 & 110 & 111 & 101 & 114 \\
\hline Nitrite & 99 & 93 & 93 & 85 & 101 & 93 & 100 & 102 \\
\hline Perchlorate & 101 & 98 & 100 & 89 & 88 & 85 & 83 & 86 \\
\hline \multirow{2}{*}{\multicolumn{9}{|c|}{$\begin{array}{l}\text { Derivatives of phosphate } \\
\text { and phosphate analogs }\end{array}$}} \\
\hline & & & & & & & & \\
\hline Pyrophosphate & 100 & 95 & 94 & 90 & 86 & 95 & 77 & 89 \\
\hline Phosphomycin & 101 & 105 & 104 & 104 & 106 & 104 & 107 & 102 \\
\hline$\beta$ - glycerophosphate & 100 & 100 & 103 & 103 & 101 & 101 & 99 & 98 \\
\hline Vanadylsulfate & 99 & 49 & 35 & 14 & 72 & 26 & 11 & 5 \\
\hline ATP & 109 & 112 & 109 & 120 & 90 & 94 & 95 & 98 \\
\hline$\alpha$ - naphtyl acid phosphate & 101 & 102 & 103 & 102 & 109 & 112 & 121 & 120 \\
\hline Phosphorus trisulfide & 98 & 100 & 100 & 98 & 106 & 115 & 112 & 101 \\
\hline $\mathrm{BpV}^{*}$ & 78 & 25 & 11 & 5 & 55 & 19 & 11 & 5 \\
\hline Phospho molybdate (PM) & 3 & 3 & 3 & 4 & 4 & 3 & 3 & 3 \\
\hline Phospho tungstate (PT) & 8 & 3 & 3 & 2 & 5 & 4 & 3 & 2 \\
\hline
\end{tabular}

${ }^{*}$ a peroxovanadium compound (Posner et al., 1994) 
and SHP-1 efficiently catalyze the dephosphorylation of pNPP under physiological conditions $(\mathrm{pH} 7.5,0.15 \mathrm{M}$ $\mathrm{NaCl}$ ). As reported (Tonks et al., 1988, Barrett et al.,

Table 2. $I_{50}$ values for the product -based inhibitors against PTP-1B and SHP-1. IC $\mathrm{I}_{50}$ values were determined at $\mathrm{pH} 7.5$ by using $10 \mathrm{mM}$ pNPP as substrate.

\begin{tabular}{lcc}
\hline \multirow{2}{*}{ Compounds } & \multicolumn{2}{c}{ Enzyme } \\
\cline { 2 - 3 } & $\mathrm{PTP}-1 \mathrm{~B}(\mu \mathrm{M})$ & $\mathrm{SHP}-1(\mu \mathrm{M})$ \\
\hline Vanadate & 33 & 13 \\
Molybdate & 21 & 12 \\
Tungstate & 25 & 17 \\
Thiophosphate & $\mathrm{ND}$ & 91 \\
Vandyl sulfate & 57 & 24 \\
BpV & 23 & 11 \\
Phosphomolybdate (PM) & 0.15 & 0.12 \\
Phosphotungstate (PT) & 1.5 & 3.1 \\
\hline
\end{tabular}

$\mathrm{ND}$ : not determined

(A)

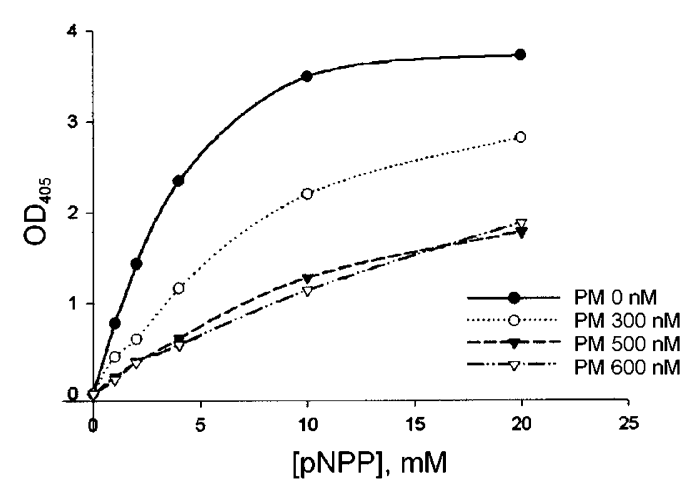

(B)

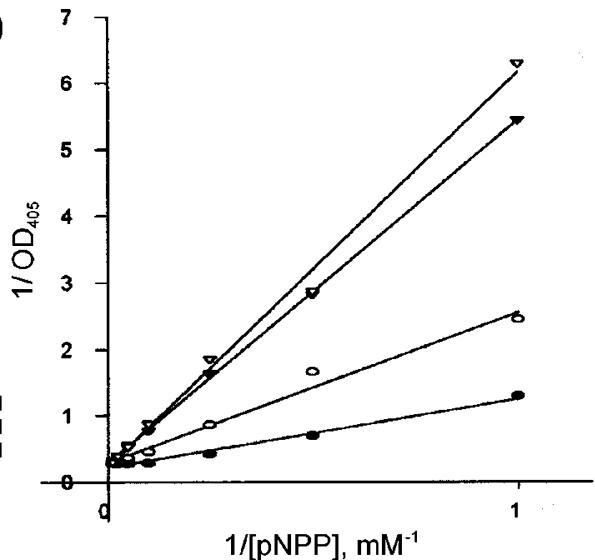

(C)



(D)



Figure 1. Kinetic analyses of PTP-1B inhibition by phosphomolybdate and phosphotungstate. (A) The reaction rate as a function of substrate concentration for PTP-1B under various phosphomolybdate concentrations. (B) Lineweaver-Burke plot of PTP-1B inhibition by phosphomolybdate. Total inhibitor concentrations, bottom to top curves: $0 \mathrm{nM}, 300 \mathrm{nM}, 500 \mathrm{nM}, 600 \mathrm{nM}$. (C) The reaction rate as a function of substrate concentration for PTP-1B under various phosphotungstate concentrations. (D) Lineweaver-Burke plot of PTP-1B inhibition by phosphotungstate. Total inhibitor concentrations, bottom to top curves: 0 $\mu \mathrm{M}, 1 \mu \mathrm{M}, 2 \mu \mathrm{M}, 3 \mu \mathrm{M}$. 
(A)

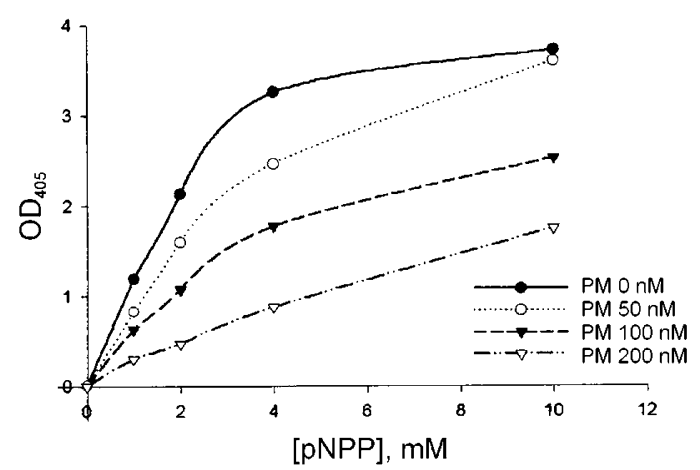

(C)

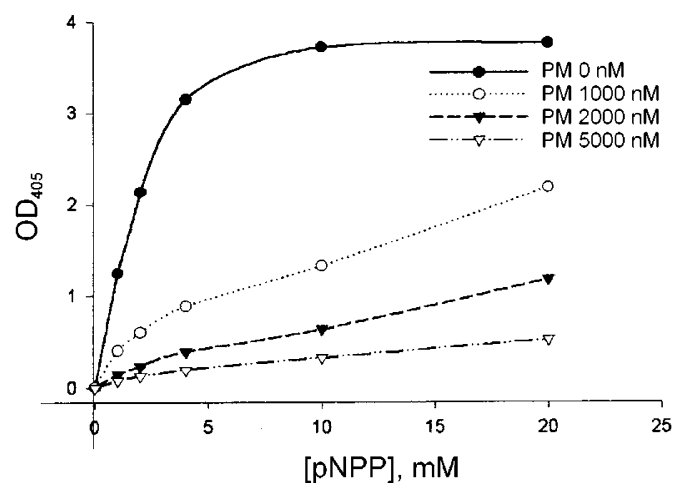

(B)

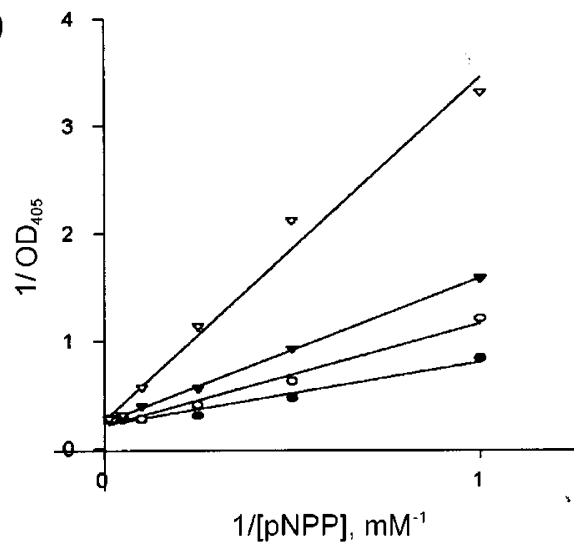

(D)



Figure 2. Kinetic analyses of SHP-1 inhibition by phosphomolybdate and phosphotungstate. (A) The reaction rate as a function of substrate concentration for SHP-1 under various phosphomolybdate concentrations. (B) Lineweaver-Burke plot of SHP-1 inhibition by phosphomolybdate. Total inhibitor concentrations, bottom to top curves: $0 \mathrm{nM}, 50 \mathrm{nM}, 100 \mathrm{nM}, 200 \mathrm{nM}$. (C) The reaction rate as a function of substrate concentration for SHP-1 under various phosphotungstate concentrations. (D) Lineweaver-Burke plot of SHP-1 inhibition by phosphotungstate. Total inhibitor concentrations, bottom to top curves: $0 \mu \mathrm{M}, 1 \mu \mathrm{M}, 2 \mu \mathrm{M}$, $5 \mu \mathrm{M}$.

\section{Screening of product-based inhibitors against PTP- 1B and SHP-1}

Using the purified PTPs, and the established enzyme assay system, we systematically screened the phosphate analogs, which have similar structure to phosphate, and derivatives of phosphate/phosphate analogs, that have at least one phosphate or phosphate analogue moiety in their molecular structure, for PTP inhibition. As shown in Table 1, we screened ten phosphate analogs and ten derivatives of phosphate/ phosphate analogs, based on the observation that phosphate, inhibits PTP activity with a $K_{\mathrm{i}}$ value of 4.8 $\mathrm{mM}$ (Zhang, 1995). Among the ten phosphate analogs tested, vanadate, molybdate and tungstate inhibited both PTP-1B and SHP-1 effectively, while, phosphate, sulfate, thiosulfate, and nitrate did not significantly inhibit the PTPs (Table 1). Interestingly, thiophosphate did not inhibit PTP-1B up to a concentration of $200 \mu \mathrm{M}$, but significantly inhibited SHP-1, suggesting that thiophosphate is a selective inhibitor of SHP-1. Among the ten derivatives of phosphate/phosphate analogs, a peroxovanadium compound, bpV (Posner et al., 1994), appeared to inhibit both PTP-1B and SHP-1 almost as effectively as vanadate. Vanadylsulfate also appeared to inhibit the PTPs significantly (Table 1). Remarkably, polyanionic Keggin compounds, phosphomolybdate (PM) and phosphotungstate (PT), appeared to inhibit both PTPs much more strongly than vanadate, a well known, and generally used PTP inhibitor.

To quantify the inhibitory potential of the molecules, we determined the half-maximal inhibitory concentration $\left(\mathrm{IC}_{50}\right)$ for each inhibitor, which gave rise to a $50 \%$ suppression of the original enzyme activity. We observed that PM exhibited an $\mathrm{IC}_{50}$ of $0.15 \mu \mathrm{M}$ and 0.12 $\mu \mathrm{M}$, while PT showed an $\mathrm{IC}_{50}$ of $1.5 \mu \mathrm{M}$ and $3.1 \mu \mathrm{M}$ for PTP-1B and SHP-1, respectively (Table 2). On the other hand, the widely used PTP inhibitor, vanadate, gave rise to an $\mathrm{IC}_{50}$ of $33 \mu \mathrm{M}$ and $13 \mu \mathrm{M}$ for PTP-1B and SHP-1, respectively. Molybdate, tungstate, and bpV, exhibited similar inhibitory effect to vanadate, with an $\mathrm{IC}_{50}$ of 
Table 3. $K_{i}$ values for the product based inhibitors against PTP-1B and SHP-1 at pH 7.5 and pH 5.5. $K_{i}$ values were determined as indicated in Materials and Methods.

\begin{tabular}{lccc}
\hline \multirow{2}{*}{ Compoud } & \multicolumn{3}{c}{ Enzyme } \\
\cline { 2 - 4 } & PTP-1B $(\mathrm{pH} \mathrm{7.5)}$ & PTP-1B $(\mathrm{pH} 5.5)$ & SHP-1 $(\mathrm{pH} 7.5)$ \\
& $(\mu \mathrm{M})$ & $(\mu \mathrm{M})$ & $(\mu \mathrm{M})$ \\
\hline Vanadate & $5.6 \pm 0.8$ & $409.5 \pm 82.1$ & $9.3 \pm 0.9$ \\
BpV & $5.2 \pm 0.9$ & $\mathrm{ND}$ & $16.7 \pm 3.1$ \\
Molybdate & $3.7 \pm 0.6$ & $\mathrm{ND}$ & $1.3 \pm 0.2$ \\
Phosphomolybdate & $0.16 \pm 0.02$ & $1.41 \pm 0.55$ & $0.06 \pm 0.01$ \\
Tungstate & $17.7 \pm 0.8$ & $\mathrm{ND}$ & $4.5 \pm 0.7$ \\
Phosphotungstate & $1.2 \pm 0.2$ & $10.5 \pm 0.2$ & $0.79 \pm 0.0$ \\
\hline
\end{tabular}

ND : not determined

20 30 $\mu \mathrm{M}$ for PTP-1B and 10 20 $\mu \mathrm{M}$ for SHP-1. Thiophosphate selectively inhibited SHP-1 only, with an $\mathrm{IC}_{50}$ of $\sim 90 \mu \mathrm{M}$. These results clearly indicate that PM and PT are the most potent inhibitors among various product-based PTP inhibitors, and that thiophosphate is a specific inhibitor for SHP-1.

\section{PM and PT are competitive, reversible inhibitors of PTP-1B and SHP-1}

Next, we determined the $K_{\mathrm{i}}$ values for the product-based inhibitors, against PTP-1B and SHP-1, using Lineweaver-Burk plots (Figures 1 and 2). The inhibition kinetics of PM and PT appeared to be those of competitive inhibitors, with $K_{\mathrm{i}}$ of 0.16 and $1.2 \mu \mathrm{M}$ against PTP-1B, and with $K_{\mathrm{i}}$ of 0.06 and $0.79 \mu \mathrm{M}$ against SHP1 at $\mathrm{pH}$ 7.5, respectively (Table 3). Inhibition of PTP activity, by PM and PT, was almost completely reversed when the reaction mixture was diluted or dialyzed, and the inhibition was not affected, regardless of the preincubation between the enzyme and inhibitors (data not shown), indicating that PM and PT are reversible inhibitors. The patterns of inhibition by vanadate, molybdate, and tungstate all correspond to that expected for competitive inhibition, with $K_{\mathrm{i}}$ of $5.6,3.7$ and 17.7 $\mu \mathrm{M}$, for PTP-1B and 9.3, 1.3, and $4.5 \mu \mathrm{M}$ for SHP-1 at $\mathrm{pH} 7.5$, respectively (Table 3). At neutral pH 7.5, the observed affinity, of PM and PT, for PTP-1B $\left(K_{\mathrm{i}}\right.$ $=0.16$ and $1.2 \mu \mathrm{M}$, respectively) is about 40 - and 5 -fold higher than that of vanadate $\left(K_{i}=5.6 \mu \mathrm{M}\right)$. The observed affinity of PM and PT for SHP-1 is also about 150- and 10-fold higher than that of vanadate. PM and PT potently inhibited PTPs when the reactions were assayed using phosphotyrosine containing peptides as substrate (data not shown).

$K_{\mathrm{i}}$ values of PM and PT against PTP-1B appeared to be dependent on $\mathrm{pH}$, with about a 10-fold lower potency at $\mathrm{pH} 5.5$ than at $\mathrm{pH} 7.5$ (Table 3). Even at pH 5.5, the optimal pH of PTP-1B, the observed affinity of PM and PT for PTP-1B is about 300- and 40-fold higher than that of the vanadate (Table 3). Interestingly, unlike the product-based PTP inhibitors such as vanadate, PM, and PT, small organic molecule inhibitors such as OBA and its derivatives, are known to inhibit PTPs more effectively at $\mathrm{pH} 5.5$ than at $\mathrm{pH} 7.5$ (Andersen et al., 2000, Iversen et al., 2000), and $F_{2} P m p$, containing phosphotyrosyl mimetic inhibitors, appear to potently inhibit PTPs independent of pHs (Chen et al., 1995).

\section{Effect of EDTA on the PTP-1B inhibition by PM and PT}

EDTA is known to chelate vanadium compounds, and thus significantly decreases their inhibition potencies (Huyer et al., 1998). To investigate the effect of EDTA on the PTP-1B inhibition by PM and PT, PTP inhibition assays were performed in the absence of EDTA. PTP1B prepared in the absence of EDTA was used for this purpose. As expected, $I_{50}$ values of vanadate, molybdate and tungstate were significantly decreased in the absence of EDTA (Table 4). However, IC $_{50}$ values of PM and PT were less affected, suggesting that EDTA chelates less weakly with these molecules than with the vanadate. Consequently, inhibition competencies of vanadate and PM appeared to be similar in the absence of EDTA.

Table 4. Half-maximal inhibitory concentration $\left(\mathrm{IC}_{50}\right)$ values of the product based inhibitors for PTP-1B in the absence of EDTA

\begin{tabular}{l|c}
\hline \multicolumn{1}{c|}{ Inhibitor } & $\mathrm{IC}_{50}(\mu \mathrm{M})$ \\
\hline Vanadate & 0.2 \\
Molybdate & 4.2 \\
Tungstate & $\mathrm{ND}$ \\
Thiophosphate & $\mathrm{ND}$ \\
Vandyl sulfate & 0.2 \\
BpV & 0.2 \\
Phosphomolybdate & 0.3 \\
Phosphotungstate & 0.7 \\
\hline
\end{tabular}

ND : not determined 

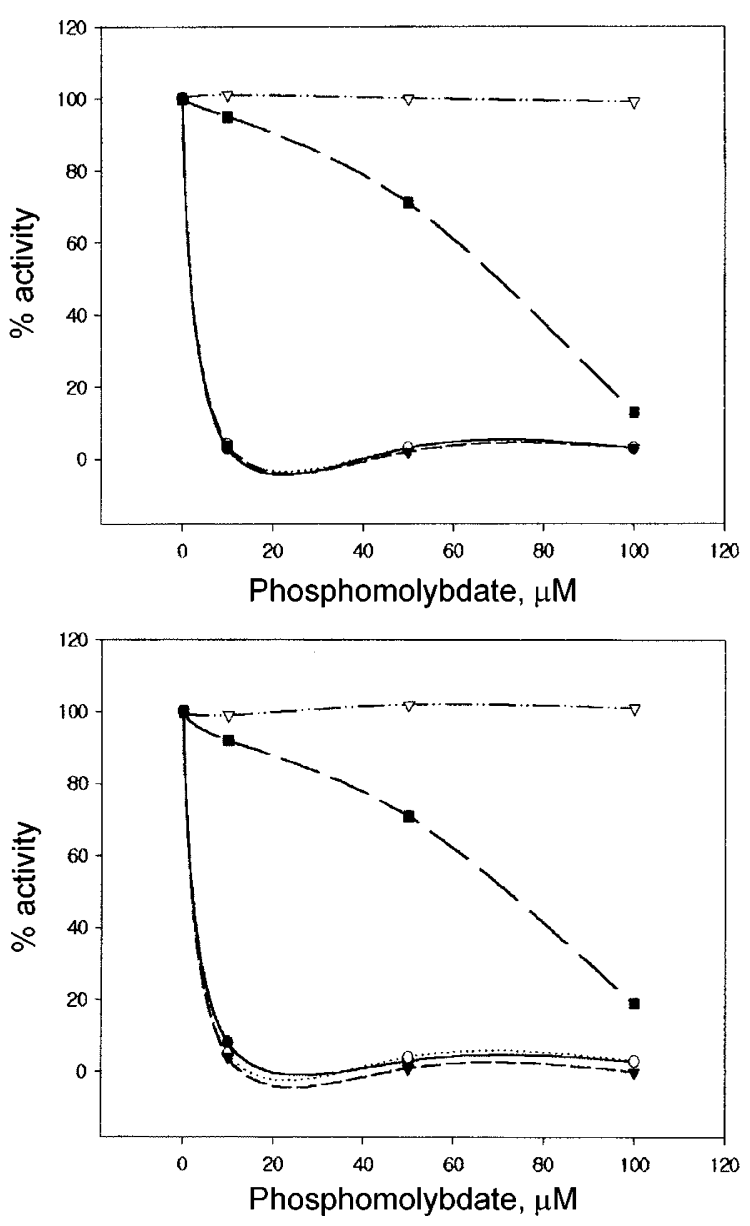

Figure 3. Concentration-dependent inhibition of PTP-1B, SHP-1, LAR, CIP, and PP1 by phosphomolybdate (upper panel) and phosphotungstate (lower panel). PTP-1B activity is designated by open circles $(\bigcirc)$ as a function of inhibitor concentration; SHP-1 activity is by closed circles (O); LAR activity is by closed triangles ( $\mathbf{\nabla})$; PP1 activity is by closed squares $(\boldsymbol{\square})$; and CIP activity is by open triangles $(\triangle)$

\section{Phosphatase specificity of PM and PT}

We investigated whether PM and PT can inhibit other phosphatase families, such as receptor tyrosine phosphatase (LAR), Ser/Thr phosphatase (PP1), and alkaline phosphatase (CIP), as well as cytosolic PTPs such as PTP-1B and SHP-1. As shown in Figure 3, $P M$ and $P T$ effectively inhibited $L A R$ with $I_{50}$ values less than $5 \mu \mathrm{M}$, though less in the cases of PTP-1B or SHP-1 (Table 2). The catalytic activity of CIP was not affected by PM and PT at all, while that of PP1 was slightly inhibited with $\mathrm{IC}_{50}$ of about $70 \mu \mathrm{M}$. These results indicate $\mathrm{PM}$ and $\mathrm{PT}$ to be very potent PTP inhibitors, but they are not strong inhibitors against alkaline phos-phatase and Ser/Thr phosphatase.

\section{Inhibition mechanism of PTP-1B by PM}

To understand how the Keggin compounds inhibit PTPs, we determined the crystal structure of PTP-1B complexed with $\mathrm{PM}$, at $2.0 \AA$ resolution, using the molecular replacement method. The initial Fo-Fc map, calculated after rigid body refinement of the PTP-1B structure (Barford, et al., 1994), showed a strong electron density $(>6 \sigma)$ near the S $\gamma$ atom of the Cys215. The 2Fo-Fc omit map, calculated after simulated annealing refinement, clearly exhibited a trigonal, pyramid-shaped electron density at the active site (Figure 4A). The electron density resembles that of the $\mathrm{MoO}_{3}$ monomer calculated by density functional theory using the Gaussian 94 program, and predicted by IR absorption analysis. Therefore, it is highly likely the well-defined electron density at the active site is that of $\mathrm{MoO}_{3}$ which must

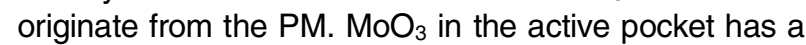
trigonal pyramid structure with a $\mathrm{M}-\mathrm{O}$ bond length of $1.74 \AA$ and O-M-O bond angle of $109.6^{\circ}$. This result
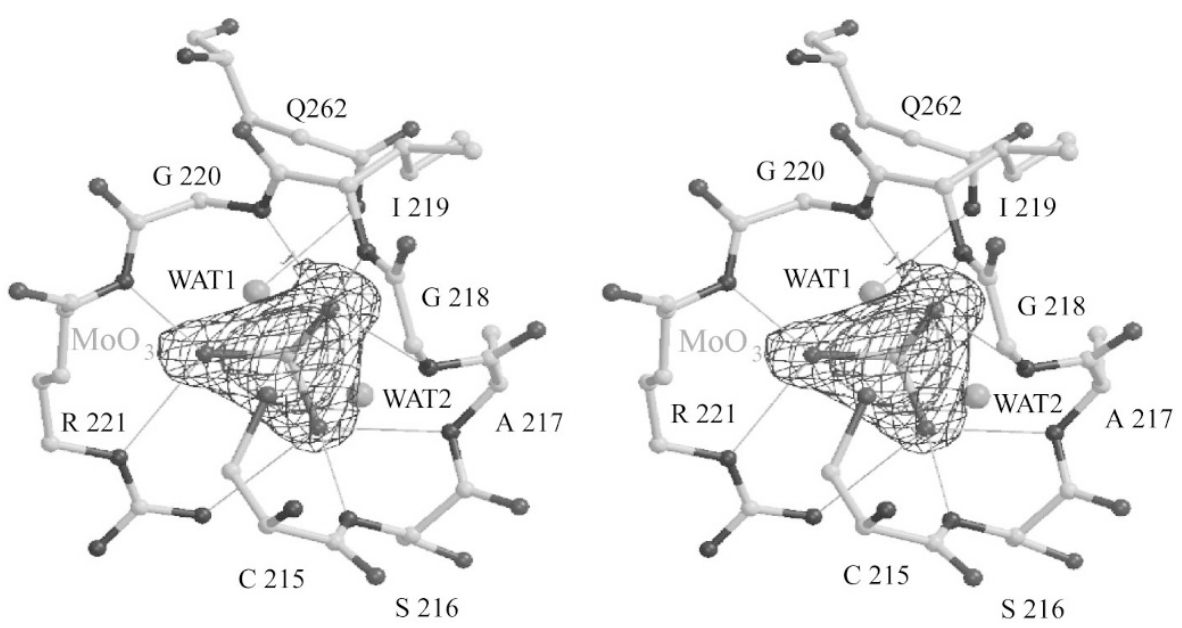

Figure 4. The stereo view of a 2Fo-Fc omit map at the active site. Contour levels are 1.3 and 6 , respectively. The side chain of Gln262, inhibitor molecule $\left(\mathrm{MoO}_{3}\right)$, and the coordinated water molecules (WAT1 and WAT2) have been omitted from the model during the simulated annealing refinement. The three oxygen atoms of $\mathrm{MoO}_{3}$ interact with the main-chain nitrogen and side chain of Arg221 in the PTP signaling motif, forming tight hydrogen bonds. The amide side chain of Gln262 forms a hydrogen bond with one of coordinated water molecule (WAT1). 
suggests that $\mathrm{MoO}_{3}$ derived from PM, by hydrolysis, binds at the active site and consequently inhibits PTP1B. In support of the crystallographic finding, we observed the molybdenum oxides $\left(\mathrm{MoO}_{3}, \mathrm{MoO}_{2}\right.$ and $\mathrm{MoO}_{2} \mathrm{Cl}_{2}$ ) inhibited PTP-1B with $\mathrm{IC}_{50}$ in the range 5-15 $\mu \mathrm{M}$ (data not shown).

The three oxygen atoms of $\mathrm{MoO}_{3}$ form eight tight hydrogen bonds to the main-chain NH group of the PTP signature motif (residue 215-221), and the side chain of Arg221, and the molybdenum atom is located adjacent to the nucleophilic sulfur of the Cys215. The side chain of Arg221 adopts its optimum conformation for electrostatic/hydrogen bonding interactions with the bound $\mathrm{MoO}_{3}$ (Figure 4). Interestingly, two water molecules (WAT1 and WAT2) are found in close proximity to the $\mathrm{Mo}$ atom of $\mathrm{MoO}_{3}$ (Figure 5). Thus the molybdenum atom of the inhibitor is coordinated with six ligands: three oxo-ligands from $\mathrm{MoO}_{3}$, two apical water molecules and a $S$ atom of the catalytic cysteine residue (Figure 5). The Mo-WAT1 and Mo-WAT2 distances are $3.31 \AA$ and $3.34 \AA$, respectively, and the Mo-S $\gamma$ distance is $3.12 \AA$. Interestingly, the coordinated WAT1 molecule attracts the side chain of Gln262 into the active site by forming a hydrogen bond with the N2-WAT1 distance of $2.91 \AA$ (Figure 4; Figure 6C), while the GIn262 is away from the active site in the unliganded PTP-1B structure (Barford et al., 1994). This movement of the Gln261 side chain has also been observed in the tungstate, and vanadate, complexed PTP-1B structures (Figure 6A and B) (Barford et al., 1994, Pannifer et al., 1998).

\section{Discussion}

Previous studies have shown that PTPs can be inhibited by phosphate, the end product of PTP catalyzed reaction, with a $K_{\mathrm{i}}$ value in the milimolar range (Zhang, 1995), and by phosphate analogs such as vanadate with a $K_{\mathrm{i}}$ value in the micromolar range (Swarup et al., 1982, Huyer et al., 1997). In this study, using the purified recombinant PTPs and pNPP as substrate, we have systematically investigated the inhibitory potentials of diverse compounds that have at least one phosphate, or phosphate analog moiety, in their molecular structures. As expected, phosphate analogs such as vanadate, molybdate, and tungstate appear to effectively inhibit both PTP-1B and SHP-1, with $K_{\mathrm{i}}$ values in micromolar ranges under the assay conditions used. Interestingly, thiophosphate appears to selectively inhibit SHP-1, and derivatives of vanadate such as peroxovanadyl compounds (Posner et al., 1994) and vanadylsulfate also appears to effectively inhibit both PTP-1B and SHP-1. Most importantly, our kinetic data indicate that phosphomolybdate (PM) and phos-photungstate (PT) work as potent, competitive, and reversible inhibitors against PTP-1B and SHP-1. PM and PT appear to strongly inhibit other PTPs such as LAR, but they weakly inhibit Ser/Thr phosphatase, but do not inhibit alkaline phosphatase at all. Unexpectedly, the crystal structure of PTP-1B complexed with PM reveals that $\mathrm{MoO}_{3}$, derived from $\mathrm{PM}$ by hydrolysis, binds at the active site. The molybdenum atom of the inhibitor is sixcoordinated with three oxo-ligands from $\mathrm{MoO}_{3}$, two apical water molecules and a $\mathrm{S}$ atom from the catalytic cysteine residue.

Our kinetic analyses show that PM and $\mathrm{PT}$ reversibly inhibit PTPs, with $K_{\mathrm{i}}$ values in the nanomolar range, in the presence of $1 \mathrm{mM}$ EDTA. These $K_{\mathrm{i}}$ values are about 50 times lower than the $K_{\mathrm{i}}$ value of vanadate (Table 3 ). Most of the potent PTP inhibitors so far reported display $K_{\mathrm{i}}$ values in the hundred-nanomolar range. For example, the $K_{\mathrm{i}}$ value of vanadate against PTP-1B has been reported to be $0.38 \mu \mathrm{M}$ in the absence of EDTA (Huyer et al., 1997). The lowest $K_{\mathrm{i}}$ value of the $\mathrm{F}_{2} \mathrm{Pmp}$ containing peptide, against rat PTP1, has been reported to be $0.12 \mu \mathrm{M}$ at $\mathrm{pH} 7.0$ (Chen et al., 1995). Recently, Iverson et al. (2000) reported the $K_{\mathrm{i}}$ value of an OBA derivative, against PTP-1B, as $0.29 \mu \mathrm{M}$ at $\mathrm{pH} 5.1$. Although it is difficult to directly compare the inhibition potential of those inhibitors, mainly due to the differences in the inhibition assay, PM and PT seem to be one of the most potent PTP inhibitors so far developed judging from the reported $K_{\mathrm{i}}$ values. It is clear that PM and PT inhibit PTPs much more strongly than vanadate/molybdate/tungstate in the presence of EDTA. Previous studies have shown that EDTA chelates vanadate, and consequently decreases the inhibition potential of the molecule. Our data also demonstrate that vanadate inhibits PTP-1B much more strongly in the absence of EDTA (Table 4) than in its presence (Table 2). However, the inhibition potential of PM and PT does not appear to be significantly affected by EDTA (Table 2 and Table 4). As a result, the inhibition potential of PM and PT appears to be similar to that of vanadate in the presence of EDTA.

We have shown that PM and PT are general inhibitors of PTPs (Figure 3). PM and PT potently inhibit cytoplasmic PTPs such as PTP-1B and SHP-1, and receptor-like PTPs such as LAR. However, PM and PT appear to be poor inhibitors of Ser/Thr phosphatase such as PP1. Particularly, PM and PT do not inhibit alkaline phosphatase, even at millimolar concentrations. Although PM and PT, as general and potent PTP inhibitors, lack specificity, they could be useful tools for knocking out all the PTP functions in in vitro, as well as in ex vivo, or in vivo studies. In particular, PM and PT would be more useful than vanadate for in vitro studies, since their inhibition potential is not significantly affected by EDTA.

The catalytic PTP domains contain a distinct sequence motif of 11 amino acid residues, I/VHCXXGXXRS/TG, at the active site. The Cys residue is critical in the catalytic 


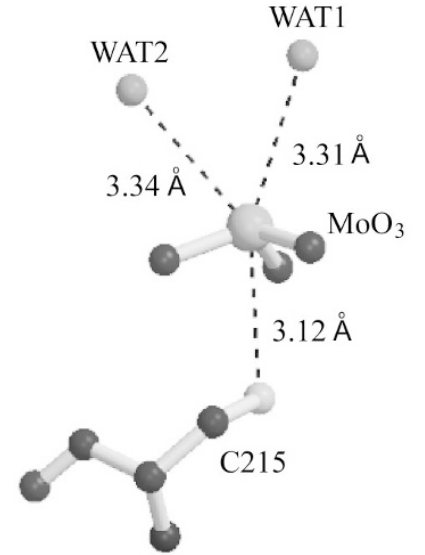

Figure 5. $\mathrm{MoO} 3$ complexed with PTP-1B, forms an extremely distorted hexavalent octahedral structure. Six-coordination is achieved by three oxoligands, two water molecules, and the S $\gamma$ atom of Cys215.

(A)
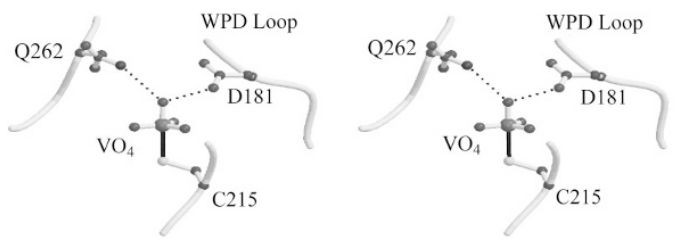

(B)

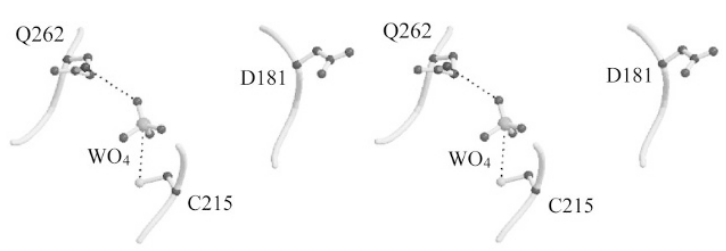

(C)

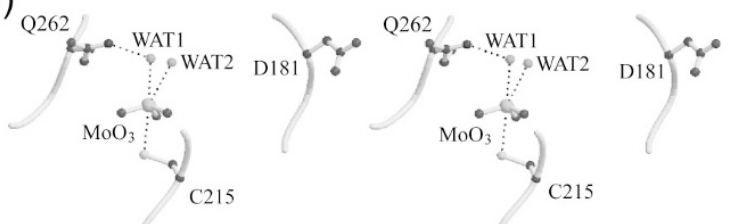

Figure 6. Comparison of the inhibitor binding sites. (A) A stereo view of PTP1B:Vanadate complex. Vanadium atom and $\mathrm{S} \gamma$ of Cys215 form a covalent bond colinear with the apical oxygen-vanadium bond. The apical oxygen is hydrogen bonded with the side chains of Gln262 and Asp181. Thus the WPD loop (residues 179-187) is closed in this structure. (B) A stereo view of PTP-1B:tungstate complex. The tungsten atom forms a covalent bond with the $S \gamma$ of Cys215, and the apical oxygen is hydrogen bonded with the side chain of Gln262. (C) A stereo view of PTP-1B: $\mathrm{MoO}_{3}$ complex. Molybdenum atom forms a covalent bond with the $S \gamma$ of Cys215, and an apical water molecule (WAT1) forms a tight hydrogen bond with the side chain of Gln262. Note that tungstate and $\mathrm{MoO}_{3}$ do not induce the closure of the WPD loop.

activity of PTPs functioning as a nucleophile that form a thiol-phosphate intermediate during catalysis (Guan and Dixon, 1991, Zhou et al., 1994). The Cys residue is easily inactivated by sulfhydryl oxidizing and alkylating agents (Zhang and Dixon, 1993). The crystal structure of PTP-1B, complexed with PM, reveals that $\mathrm{MoO}_{3}$ binds at the active site forming a thiol-molybdenum ester linkage between the Cys residue and the central molybdenum atom. Polyanionic Keggin compounds, $\mathrm{PM}\left(12 \mathrm{MoO}_{3}\right.$. $\left.\mathrm{H}_{3} \mathrm{PO}_{4}\right)$ and PT $\left(12 \mathrm{WO}_{3} \cdot \mathrm{H}_{3} \mathrm{PO}_{4}\right)$, contain twelve $\mathrm{MoO}_{3}$ or $\mathrm{WO}_{3}$ moieties, and one $\mathrm{PO}_{4}$ moiety in the molecular structure. Those Keggin compounds are known to hydrolyze in aqueous solution to an equilibrium concentration of various components. Therefore, it is highly likely that $\mathrm{MoO}_{3}$, derived from PM by hydrolysis, actually inhibits PTPs, although it is not yet known whether the Cys residue at the active site functions as a nucleophile to hydrolyze PM. Interestingly, we observed that molybdenum oxides $\left(\mathrm{MoO}_{3}, \mathrm{MoO}_{3}\right.$ and $\left.\mathrm{MoO}_{2} \mathrm{Cl}_{2}\right)$ inhibited PTPs. However, the inhibition potential of $\mathrm{MoO}_{3}$ appeared to be lower than PM, considering PM contains $12 \mathrm{MoO}_{3}$ units.

Vanadate is a phosphate analog, since it can adopt a similar structure to inorganic phosphate. The three dimensional structure of the PTP-1B complexed with vanadate reveals that the vanadate molecule occupies the active site forming a thiol-vanadyl ester linkage between the central vanadium atom and the Sã atom of Cys215, which is colinear with the apical oxygenvanadium bond (Pannifer et al., 1998). Thus the vanadate in the active site forms a pentavalent trigonal bipyramidal structure (Figure 6A). The structure of vanadate, complexed with PTP-1B, is very similar to the transition state of the cysteinyl-phosphate intermediate when being attacked by a nucleophilic water, forming a pentavalent phosphorus intermediate (Denu et al., 1996). The apical oxygen of the vanadate is hydrogen bonded with amide side chains of Gln262. The side chain of Asp181 also interacts with the apical oxygen, causing the closed conformation of the WPD loop (residues 179-187). Tungstate has also been shown to bind at the active site of PTP (Barford et al., 1994), forming a distorted trigonal bipyramidal structure. However, in the tungstate-complexed PTP-1B, the side chain of Gln262 does not bind tightly to the tungstate. The shortest length, between the apical oxygen of tungstate and the amide side chain of Gln262, is just $3.8 \AA$ (Figure $6 \mathrm{~B}$ ). Similar to the case of vanadate or tungstate, $\mathrm{MoO}_{3}$ binds to the active site of the PTP-1B. However, the binding mode and conformation of $\mathrm{MoO}_{3}$, complexed with PTP-1B, appear to be quite distinct (Figure 6C). Most importantly, $\mathrm{MoO}_{3}$ bound to the active site exhibits an extremely distorted hexavalent octahedral geometry, with three oxoligands, and three additional ligands from a sulfur atom of Cys215 and from two oxygen atoms of water molecules (Figure 5). The three oxo ligands are hydrogen bonded with the amide side chain of Arg221 and the amide backbone of Ser216, Ala217, Gly218, Ile219 and Gly220 (Figure 4). One of the water ligands (WAT1) is hydrogen bonded more tightly with the amide side chain of Gln262 than in the case of vanadate or tungstate (Figure $6 \mathrm{C}$ ). 
Table 5. Crystal, data collection, and refinement statistics

\begin{tabular}{|c|c|}
\hline \multicolumn{2}{|l|}{ Crystal Parameters } \\
\hline Space group & $\mathrm{P} 3,21$ \\
\hline Cell constants & $\begin{array}{l}a=b=88.36 \AA, c=14.91 \AA \\
a=b=90^{\circ}, g=120^{\circ}\end{array}$ \\
\hline \multicolumn{2}{|c|}{ Data collection and processing statistics } \\
\hline Resolution range $(\AA ̊)$ & $100-2.0(2.07-2.0)^{\mathrm{a}}$ \\
\hline Unique reflections $(I>0 s)$ & 31250 (2939) \\
\hline Completeness (\%) & 95.8(91.9) \\
\hline $\mathrm{R}_{\text {sym }}^{\mathrm{b}}$ & $0.049(0.184)$ \\
\hline$l>s$ & $21.2(7.3)$ \\
\hline Wavelength $(\AA)$ & 1.1764 \\
\hline \multicolumn{2}{|l|}{ Refinement statistics } \\
\hline Resolution used $(\AA ̊)$ & $20-2.0$ \\
\hline Reflections used $(I>2 \mathrm{~s})$ & $30630(2816)$ \\
\hline $\mathrm{R}_{\text {cryst }}^{c}$ & $0.217 / 0.239(0.221 / 0.252)$ \\
\hline r.m.s.d bond lengths $\left(^{\circ}\right)$ & 0.005 \\
\hline r.m.s.d bond angles $\left({ }^{\circ}\right)$ & 1.22 \\
\hline r.m.s.d dihedral $\left(^{\circ}\right)$ & 22.7 \\
\hline r.m.s.d improper $\left({ }^{\circ}\right)$ & 0.674 \\
\hline \multicolumn{2}{|l|}{ Number of atoms } \\
\hline Protein & 2266 \\
\hline Water & 118 \\
\hline $\mathrm{MoO}_{3}$ & 4 \\
\hline
\end{tabular}

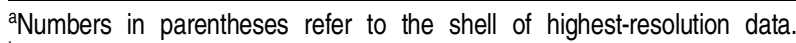


measurement of reflection $h .{ }^{c} R_{\text {cryst: }}\left(\Sigma_{h}\left|F_{o}-F_{c}\right| \Sigma_{h} F_{0}\right) \times 100$, where $F_{o}$ and $F_{c}$ are the observed and calculated structure factor amplitudes of reflection $h$.

Unlike the case of vanadate, $\mathrm{MoO}_{3}$ does not form a hydrogen bond with Asp181. As a result, the PTP-1B structure in complex with $\mathrm{MoO}_{3}$ adopts an open conformation of the WPD loop (residues 179-187), which is characteristic of the unliganded state of PTP1B (Barford et al., 1994). The open conformation of the WPD loop was also observed in the PTP1B-tungstate (Barford et al., 1994) and PTP1B-fluoromalonyl tyrosine (FOMT)-based cyclic peptide complex structures (Groves et al., 1998). It has been observed from the structure of PTP-1B complexed with a FOMT-based cyclic peptide, which has a $K_{\mathrm{i}}$ value of $0.17 \mathrm{mM}$, the closure of the WPD loop is not essential for the high inhibitory potential of PTP inhibitor. If the present structure PTP-1B: $\mathrm{MoO}_{3}$ complex would adopt the closed form of the WPD loop, Asp181 could improve the $\mathrm{MoO}_{3}$ binding affinity by hydrogen bonding to the highly ordered WAT2 molecule. However, the fact the binding of $\mathrm{MoO}_{3}$ does not induces closure of the WPD loop, the inhibitory potential is not expected to be improved much by the simple closure of the WPD loop, without any additional interactions such as aromatic-aromatic interaction between the side chain of Phe182 and an aromatic moiety of an inhibitor.

Many attempts have already been made to develop vanadium derivatives with high potency, high selectivity, and low toxicity. For example, vanadylsulfate and vanadyl[bis(maltalato)oxovanadium (IV)] have been synthesized, and shown to inhibit PTPs with similar potency to vanadate (Yuen et al., 1993). A variety of vanadate complexes including bismaltooxovanadates, and peroxovanadates with different ancillary ligands, have been synthesized. Some of these have been shown to increase the level of insulin receptor phosphorylation (Posner et al., 1994, Poucheret et al., 1998). Recently, a complex of vanadate with dimethylhydroxylamine has been synthesized and shown to reversibly inhibit PTP-1B and LAR, with a $K_{i}$ in the micromolar range. Similar approaches would be worth trying with $\mathrm{MoO}_{3}$ in an attempt to come up with more selective and cellularly active, but less toxic, PTP inhibitors. Highly selective and potent PTP inhibitors could be used as essential tools in revealing the biological function of specific PTPs, as well as having high potential as therapeutic agents.

\section{Acknowledgments}

We thank Drs. S. R. Paik and Y. H. Kim for their helpful discussions, Dr. T. D. Kim and H. Y. Chung for their technical assistance, and Dr. Hueng-Soo Lee and Kyung-Hwa Kim for their assistance with the Pohang Light Source (PLS), beamline 6B. Experiments at PLS were supported in part by MOST and POSCO. This work was supported in part by a grant of the 99 Good Health R and D project (HMP-99-M-08-0003), Ministry of Health and Welfare, Korea.

\section{References}

Andersen HS, Iversen LF, Jeppesen CB, Branner S, Norris K, Rasmussen HB, Moller KB, Moller NP. 2-(oxalylamino)-benzoic acid is a general, competitive inhibitor of protein-tyrosine phosphatases. J Biol Chem 2000;275:7101-8

Barford D, Flint AJ, Tonks, NK. Crystal structure of human protein tyrosine phosphatase 1B. Science 1994; 263:1397-404

Barrett WC, DeGnore JP, Keng YF, Zhang ZY, Yim MB, Chock, PB. Roles of superoxide radical anion in signal transduction mediated by reversible regulation of proteintyrosine phosphatase 1B. J Biol Chem 1999;274:34543-46

Brunger AT, Adams PD, Clore GM, DeLano WL, Gros P, Grosse-Kunstleve RW, Jiang JS, Kuszewski J, Nilges M, Pannu NS, Read RJ, Rice LM, Simonson T, Warren GL. Crystallography and NMR system: A new software suite for macromolecular structure determination. Acta Crystallogr D 
Biol Crystallogr 1998;54 (Pt 5):905-21

Burke TRJr., Kole HK and Roller PP. Potent inhibition of insulin receptor dephosphorylation by a hexamer peptide containing the phosphotyrosyl mimetic F2Pmp. Biochem Biophys Res Commun 1994;204:129-34

Burke TRJr., Ye B, Yan X, Wang S, Jia Z, Chen L, Zhang ZY, Barford, D. Small molecule interactions with protein-tyrosine phosphatase PTP1B and their use in inhibitor design. Biochemistry 1996;35:15989-96

Burke TRJr., Zhang ZY. Protein-tyrosine phosphatases: structure, mechanism, and inhibitor discovery. Biopolymers 1998;47:225-41

Chen L, Montserat J, Lawrence DS, Zhang ZY. VHR and PTP1 protein phosphatases exhibit remarkably different active site specificities toward low molecular weight nonpeptidic substrates. Biochemistry 1996;35:9349-54

Chen L, Wu L, Otaka A, Smyth MS, Roller PP, Burke TRJr., den Hertog $\mathrm{J}$ and Zhang, ZY. Why is phosphonodifluoromethyl phenylalanine a more potent inhibitory moiety than phosphonomethyl phenylalanine toward protein-tyrosine phosphatases? Biochem Biophys Res Commun 1995; 216:976-84

Chernoff J, Schievella AR, Jost CA, Erikson RL, Neel BG. Cloning of a cDNA for a major human protein-tyrosinephosphatase. Proc Natl Acad Sci U S A 1990;87:2735-39

Cote JF, Charest A, Wagner J, Tremblay ML. Combination of gene targeting and substrate trapping to identify substrates of protein tyrosine phosphatases using PTP-PEST as a model. Biochemistry 1998;37:13128-37

Denu JM, Dixon JE. Protein tyrosine phosphatases: mechanisms of catalysis and regulation. Curr Opin Chem Biol 1998;2:633-41

Denu JM, Lohse DL, Vijayalakshmi J, Saper MA, Dixon JE. Visualization of intermediate and transition-state struc-tures in protein-tyrosine phosphatase catalysis. Proc Natl Acad Sci U SA 1996;93:2493-98

Desmarais S, Friesen RW, Zamboni R, Ramachandran C. [Difluro(phosphono)methyl]phenylalanine-containing peptide inhibitors of protein tyrosine phosphatases. Biochem $\mathrm{J}$ 1999;337(Pt 2):219-23

Elchebly M, Payette P, Michaliszyn E, Cromlish W, Collins S, Loy AL, Normandin D, Cheng A, Himms-Hagen J, Chan CC, Ramachandran C, Gresser MJ, Tremblay ML, Kennedy BP. Increased insulin sensitivity and obesity resistance in mice lacking the protein tyrosine phosphatase-1B gene. Science 1999a;283:1544-48

Elchebly M, Wagner J, Kennedy TE, Lanctot C, Michaliszyn E, Itie A, Drouin J, Tremblay ML. Neuroendocrine dysplasia in mice lacking protein tyrosine phosphatase sigma. Nat Genet 1999b;21:330-33

Fischer $\mathrm{EH}$, Charbonneau, $\mathrm{H}$ and Tonks, NK. Protein tyrosine phosphatases: a diverse family of intracellular and transmembrane enzymes. Science 1991;253:401-6

Garboczi DN, Hung DT, Wiley DC. HLA-A2-peptide complexes: refolding and crystallization of molecules expressed in Escherichia coli and complexed with single antigenic peptides. Proc Natl Acad Sci USA 1992;89:3429-33

Groves MR, Yao ZJ, Roller PP, Burke TRJr., Barford D. Structural basis for inhibition of the protein tyrosine phosphatase $1 \mathrm{~B}$ by phosphotyrosine peptide mimetics. Biochemistry 1998;37:17773-83

Guan KL and Dixon JE. Evidence for protein-tyrosinephosphatase catalysis proceeding via a cysteine-phosphate intermediate. J Biol Chem 1991;266:17026-30

Hooft van Huijsduijnen, R Protein tyrosine phosphatases: counting the trees in the forest. Gene 1998;225:1-8

Hunter T. Protein kinases and phosphatases: the yin and yang of protein phosphorylation and signaling. Cell 1995; 80:225-36

Huyer G, Kelly J, Moffat J, Zamboni R, Jia Z, Gresser MJ, Ramachandran C. Affinity selection from peptide libraries to determine substrate specificity of protein tyrosine phosphatases. Anal Biochem 1998;258:19-30

Huyer G, Liu S, Kelly J, Moffat J, Payette P, Kennedy B, Tsaprailis G, Gresser MJ, Ramachandran C. Mechanism of inhibition of protein-tyrosine phosphatases by vanadate and pervanadate. J Biol Chem 1997;272:843-51

Iversen LF, Andersen HS, Branner S, Mortensen SB, Peters $\mathrm{GH}$, Norris K, Olsen OH, Jeppesen CB, Lundt BF, Ripka W, Moller KB, Moller NP. Structure-based design of a low molecular weight, nonphosphorus, nonpeptide, and highly selective inhibitor of protein-tyrosine phosphatase 1B. J Biol Chem 2000;275:10300-7

Jiang, JS, Brunger AT. Protein hydration observed by X-ray diffraction. Solvation properties of penicillopepsin and neuraminidase crystal structures. J Mol Biol 1994;243:100-15

Kennedy BP, Ramachandran C. Protein tyrosine phosphatase1B in diabetes. Biochem Pharmacol 2000;60: 877-83

Kim J, Chwae, YJ Kim, MY Choi, IH Park, JH, Kim SJ. Molecular basis of HLA-C recognition by p58 natural killer cell inhibitory receptors. J Immunol 1997;159:3875-82

Kishihara K, Penninger J, Wallace VA, Kundig TM, Kawai K, Wakeham A, Timms E, Pfeffer K, Ohashi PS, Thomas ML et al., Normal B lymphocyte development but impaired $T$ cell maturation in CD45-exon6 protein tyrosine phosphatasedeficient mice. Cell 1993;74:143-56

Kole HK, Akamatsu M, Ye B, Yan X, Barford D, Roller PP, Burke TRJr., Protein-tyrosine phosphatase inhibition by a peptide containing the phosphotyrosyl mimetic, L-Omalonyltyrosine. Biochem Biophys Res Commun 1995;209: 817-22

Liotta AS, Kole HK, Fales HM, Roth J, Bernier M. A synthetic tris-sulfotyrosyl dodecapeptide analogue of the insulin receptor 1146-kinase domain inhibits tyrosine dephosphorylation of the insulin receptor in situ. J Biol Chem 1994;269:22996-3001

Malamas MS, Sredy J, Moxham C, Katz A, Xu W, McDevitt R, Adebayo FO, Sawicki DR, Seestaller L, Sullivan D, Taylor JR. 
Novel benzofuran and benzothiophene biphenyls as inhibitors of protein tyrosine phosphatase $1 \mathrm{~b}$ with antihyper-glycemic properties. J Med Chem 2000;43:1293-310

Nee BG, Tonks NK. Protein tyrosine phosphatases in signal transduction. Curr Opin Cell Biol 1997;9:193-204

Pannifer AD, Flint AJ, Tonks NK, Barford D. Visualization of the cysteinyl-phosphate intermediate of a protein-tyrosine phosphatase by $\mathrm{x}$-ray crystallography. J Biol Chem 1998;273:10454-62

Posner BI, Faure R, Burgess JW, Bevan AP, Lachance D, Zhang-Sun G, Fantus IG, Ng JB, Hall DA, Lum BS et al., Peroxovanadium compounds. A new class of potent phosphotyrosine phosphatase inhibitors which are insulin mimetics. J Biol Chem 1994;269:4596-604

Poucheret P, Verma S, Grynpas MD, McNeill JH. Vanadium, diabetes. Mol Cell Biochem 1998;188:73-80

Ren JM, Li PM, Zhang WR, Sweet LJ, Cline G, Shulman GI, Livingston JN, Goldstein BJ. Transgenic mice deficient in the LAR protein-tyrosine phosphatase exhibit profound defects in glucose homeostasis. Diabetes 1998;47:493-97

Saxton TM, Henkemeyer M, Gasca S, Shen R, Rossi DJ, Shalaby F, Feng GS, Pawson T. Abnormal mesoderm patterning in mouse embryos mutant for the $\mathrm{SH} 2$ tyrosine phosphatase Shp-2. EMBO J 1997;16:2352-64

Schaapveld RQ, Schepens JT, Robinson GW, Attema J, Oerlemans FT, Fransen JA, Streuli M, Wieringa B, Hennighausen L, Hendriks WJ. Impaired mammary gland development and function in mice lacking LAR receptor-like tyrosine phosphatase activity. Dev Biol 1997;188:134-46

Shen SH, Bastien L, Posner BI, Chretien P. A protein-tyrosine phosphatase with sequence similarity to the $\mathrm{SH} 2$ domain of the protein-tyrosine kinases. Nature 1991;352:736-39

Shultz LD, Schweitzer PA, Rajan TV, Yi T, Ihle JN, Matthews RJ, Thomas ML, Beier DR. Mutations at the murine motheaten locus are within the hematopoietic cell proteintyrosine phosphatase (Hcph) gene. Cell 1993;73:1445-54

Swarup G, Cohen S, Garbers DL. Inhibition of membrane phosphotyrosyl-protein phosphatase activity by vanadate. Biochem Biophys Res Commun 1982;107:1104-09

Taing M, Keng YF, Shen K, Wu L, Lawrence DS, Zhang ZY. Potent and highly selective inhibitors of the protein tyrosine phosphatase 1B. Biochemistry 1999;38:3793-803
Tonks NK, Diltz CD, Fischer EH. Characterization of the major protein-tyrosine-phosphatases of human placenta. J Biol Chem 1988;263:6731-37

Tonks NK, Neel BG. From form to function: signaling by protein tyrosine phosphatases. Cell 1996;87:365-68

Tsui HW, Siminovitch KA, de Souza L, Tsui, FW. Motheaten, viable motheaten mice have mutations in the haematopoietic cell phosphatase gene. Nat Genet 1993;4: 124-29

Wang Q, Scheigetz J, Gilbert M, Snider J, Ramachandran C. Fluorescein monophosphates as fluorogenic substrates for protein tyrosine phosphatases. Biochim Biophys Acta 1999;1431:14-23

You-Ten KE, Muise ES, Itie A, Michaliszyn E, Wagner J, Jothy S, Lapp WS, Tremblay ML. Impaired bone marrow microenvironment and immune function in $\mathrm{T}$ cell protein tyrosine phosphatase-deficient mice. J Exp Med 1997;186: 683-93

Yuen VG, Orvig C and McNeill JH. Glucose-lowering effects of a new organic vanadium complex, bis (maltolato) oxovanadium(IV). Can J Physiol Pharmacol 1993;71:263-69

Zhang ZY. Kinetic and mechanistic characterization of a mammalian protein-tyrosine phosphatase, PTP1. J Biol Chem 1995;270:11199-204

Zhang ZY. Protein-tyrosine phosphatases: biological function, structural characteristics, and mechanism of catalysis. Crit Rev Biochem Mol Biol 1998;33:1-52

Zhang ZY, Dixon JE. Active site labeling of the Yersinia protein tyrosine phosphatase: the determination of the pKa of the active site cysteine and the function of the conserved histidine 402. Biochemistry 1993;32:9340-45

Zhang ZY, Dixon JE. Protein tyrosine phosphatases: mechanism of catalysis and substrate specificity. Adv Enzymol Relat Areas Mol Biol 1994;68:1-36

Zhang ZY, Maclean D, McNamara DJ, Sawyer TK, Dixon JE. Protein tyrosine phosphatase substrate specificity: size and phosphotyrosine positioning requirements in peptide substrates. Biochemistry 1994;33:2285-90

Zhou G, Denu JM, Wu L, Dixon JE. The catalytic role of Cys124 in the dual specificity phosphatase VHR. J Biol Chem 1994;269:28084-90 